\title{
Literature Review: Perbandingan Antara Rasio Harga terhadap Laba (P/E Ratio) dan Arus kas Diskonto (DCF) untuk Penilaian Perusahaan
}

\author{
Amalia Natalia \\ Universitas Sumatera Utara \\ amalianatalia05@gmail.com
}

\begin{abstract}
Abstrak
Penilaian perusahaan dalam suatu industri atau bisnis sangat diperlukan untuk mengetahui nilai intrinsik dari sebuah perusahaan. Banyak model yang bisa digunakan untuk melakukan penilaian perusahaan, diantaranya yang akan di analisis adalah Rasio Harga Terhadap Laba atau Price/Earning Ratio (P/E Ratio) dan Arus Kas Diskonto atau Discounted Cash Flow (DCF). DCF adalah arus kas yang didiskontokan dan merupakan metode penilaian yang digunakan untuk memperkirakan nilai investasi berdasarkan arus kas masa depan. P/E Ratio adalah alat utama penghitungan harga saham suatu perusahaan dibandingkan dengan pendapatan perusahaan. Metode dari penelitian ini adalah metode deskriptif dengan melakukan analisa atas penelitian-penelitian terdahulu baik yang bersumber dari jurnal, buku, dan jenis artikel terpercaya lainnya. Tujuan dari review ini adalah untuk membandingkan metode P/E Ratio dan DCF untuk menilai perusahaan dengan menggunakan data dan informasi yang didapat dari Proquest dan e-jurnal lainnya. Kesimpulan dari penelitian ini adalah Metode P/E Ratio didorong oleh kinerja pasar sementara metode DCF didasarkan pada perkiraan analisis arus kas dan tingkat diskonto. Nilai intrinsik saham yang didapatkan berdasarkan hasil analisis fundamental dengan menggunakan DCF dan PER merupakan hasil dari estimasi yang tentunya dapat menghasilkan suatu ketidakpastian dalam penilaian perusahaan, oleh karena itu sebaiknya para investor diharapkan dapat lebih berhati-hati dalam mengambil sebuah keputusan investasi.
\end{abstract}

Kata Kunci : Rasio Harga Terhadap Laba (P/E Ratio), Arus Kas Diskonto (DCF), Penilaian Perusahaan

\section{PENDAHULUAN}

Menurut Brigham dan Erdhadt (2005), nilai perusahaan merupakan nilai sekarang (present value) dari arus kas bebas (free cash flow) di masa mendatang pada tingkat diskonto sesuai ratarata tertimbang biaya modal. Arus Kas Bebas merupakan Arus Kas yang tersedia bagi investor (kreditur dan pemilik) setelah memperhitungkan seluruh pengeluaran untuk operasional perusahaan dan pengeluaran untuk investasi serta aset lancar bersih.

Cara yang dapat dilakukan untuk meminimalisir resiko yang diterima oleh investor ketika akan melakukan keputusan pembelian atau penjualan saham yaitu dengan terlebih dahulu melakukan penilaian/valuasi saham. Penilaian harga saham ini diperlukan untuk mengetahui apakah nilainya sedang wajar (correctly valued), sedang murah (undervalued), atau sedang mahal (overvalued). Naik-turunnya pergerakan harga saham membuat investor harus melakukan analisis dalam setiap keputusan yang akan dilakukan baik itu jual atau beli sesuai dengan hasil dari analisis tersebut. 
Saat memutuskan metode valuasi mana yang akan digunakan untuk menilai saham, kita akan kewalahan dengan banyaknya cara valuasi saham yang ada. Ada metode valuasi yang cukup mudah dan ada juga metode yang rumit. Tidak ada satu metode yang paling cocok untuk setiap situasi. Setiap saham berbeda, dan setiap industri atau sektor memiliki karakteristik unik yang mungkin memerlukan beberapa jenis metode valuasi.

\section{Jenis-jenis Nilai Perusahaan}

Terdapat lima jenis nilai perusahaan berdasarkan metode perhitungan yang digunakan (Yulius dan Tarigan, 2007), yaitu:

1. Nilai Nominal. Nilai nominal adalah nilai yang tercantum secara formal dalam anggaran dasar perseroan, disebutkan secara eksplisit dalam neraca perusahaan, dan juga ditulis secara jelas dalam surat saham kolektif.

2. Nilai Pasar. Nilai pasar sering disebut kurs adalah harga yang terjadi dari proses tawar menawar di pasar saham. Nilai ini hanya bisa ditentukan jika saham perusahaan dijual di pasar saham.

3. Nilai Intrinsik. Nilai intrinsik merupakan konsep yang paling abstrak, karena mengacu kepada perkiraan nilai riil suatu perusahaan. Nilai perusahaan dalam konsep nilai intrinsik ini bukan sekedar harga dari sekumpulan aset, melainkan nilai perusahaan sebagai entitas bisnis yang memiliki kemampuan menghasilkan keuntungan di kemudian hari.

4. Nilai Buku. Nilai buku adalah nilai perusahaan yang dihitung dengan dasar konsep akuntansi. Secara sederhana dihitung dengan membagi selisih antar total aset dan total utang dengan jumlah saham yang beredar.

5. Nilai Likuidasi. Nilai likuidasi adalah nilai jual seluruh aset perusahaan setelah dikurangi semua kewajiban yang harus dipenuhi. Nilai likuidasi dapat dihitung dengan cara yang sama dengan menghitung nilai buku, yaitu berdasarkan neraca performa yang disiapkan ketika suatu perusahaan akan dilikuidasi.

\section{Pengukuran Nilai Perusahaan}

Nilai perusahaan dapat diukur dengan menggunakan harga saham menggunakan rasio yang disebut rasio penilaian. Menurut Sudana (2011), Rasio Penilaian adalah suatu rasio yang terkait dengan penilaian kinerja saham perusahaan yang telah diperdagangkan di pasar modal (go public).Rasio penilaian memberikan informasi seberapa besar masyarakat menghargai perusahaan, sehingga masyarakat tertarik untuk membeli saham dengan harga yang lebih tinggi dibanding nilai bukunya.

Ada beberapa metode untuk menilai perusahaan atau saham, masing-masing dengan kekuatan dan kelemahannya sendiri. Beberapa model mencoba menjabarkan nilai intrinsik perusahaan berdasarkan laporan keuangan dan proyeksinya sendiri, sementara yang lain melihat perbandingan terhadap perusahaan-perusahaan pada industri yang sejenis. Metode valuasi saham biasanya terbagi dalam dua kategori utama, yaitu; Absolute Valuation (Model valuasi absolut) dan Relative Valuation (Model valuasi relatif).

Model valuasi absolut mencoba menemukan nilai intrinsik atau "sebenarnya" dari sebuah investasi hanya berdasarkan pada fundamental. Melihat fundamental artinya investor hanya fokus pada hal-hal seperti dividen, arus kas, dan tingkat pertumbuhan untuk satu perusahaan dan tidak mengkhawatirkan perusahaan lain. Model penilaian yang termasuk dalam kategori ini antara lain model dividend discount model, discounted cash flow model, residual income model, dan asset based model. 
Model valuasi relatif dapat diaplikasikan dengan membandingkan perusahaan yang bersangkutan dengan perusahaan serupa atau di industri yang sama. Metode ini melibatkan penghitungan kelipatan dan rasio, seperti rasio harga terhadap laba per saham (P/E Ratio), dan membandingkannya dengan perusahaan serupa di industri yang sama.

Demirakos et al. ( 2010) menunjukkan bahwa Rasio Laba Per Saham (P/E Ratio) dan Arus Kas Diskonto (DCF) adalah dua model penilaian yang paling banyak digunakan oleh analis.

Disini penulis akan memfokuskan penelitian pada perbandingan DCF dari model valuasi absolut dan Rasio P/E dari model valuasi relatif untuk penilaian perusahaan.

\section{METODE PENELITIAN}

Penelitian ini menggunakan metode deskriptif dengan melakukan analisa atas penelitianpenelitian terdahulu baik yang bersumber dari jurnal, buku, dan jenis artikel terpercaya lainnya.

\section{HASIL DAN PEMBAHASAN}

\section{Rasio Harga Terhadap Laba (Price/Earning Ratio Atau P/E Ratio)}

Rasio P/E adalah salah satu tools indikator yang sangat sederhana, yang digunakan untuk menentukan apakah suatu saham termasuk ke dalam kategori "mahal" atau ""murah". PER adalah rasio keuangan yang didapatkan dari perbandingan harga saham dengan Earnings per Share (EPS). Earning per Share sendiri adalah Laba Bersih per Lembar Saham. Earnings per Share (EPS) dapat dihitung secara sederhana dengan membagi Laba Bersih dengan Jumlah Lembar Saham. Pendekatan P/E Ratio merupakan pendekatan yang populer dan sering dipakai di kalangan analis saham dan para praktisi (Tandelilin, 2010:320).

PER adalah jembatan penghubung antara kinerja pasar/market (yang diwakili oleh harga saham) dengan kinerja fundamental perusahaan (yang diwakili oleh laba). Jika keputusan untuk membeli/menjual saham hanya didasarkan pada analisa harga saham saja (analisa teknikal saja) tanpa mempertimbangkan fundamental perusahaan, maka beresiko terkena crash (lonjakan harga yang sangat tiba-tiba ketika berita fundamental release tanpa diduga sebelumnya). Jika keputusan hanya didasarkan pada fundamental perusahaan saja tanpa mempertimbangkan analisa market, maka beresiko membeli saham terlalu mahal sehingga ruang pertumbuhan harga saham sangat sempit bahkan bisa cenderung turun.

Mengetahui nilai PER saja tidak cukup berguna untuk membuat kesimpulan. Diperlukan pembanding untuk mengetahui posisi PER saat ini, apakah sudah cukup mengindikasikan harga saham yang mahal atau murah.

Ada dua macam pembanding. Pembanding yang pertama adalah perusahaan lain (kompetitor) dalam industri yang sama. Analisa awal, jika PER lebih rendah daripada rata-rata PER industri, maka saham itu adalah relatif lebih murah jika dibandingkan dengan saham-saham kompetitornya. Apakah saham yang murah itu suatu saat nanti akan naik? Belum tentu, karena kalau fundamental semakin buruk maka bisa jadi sahamnya akan ikut lebih buruk lagi. Pembanding yang kedua adalah rata-rata histori (masa lalu) PER saham itu sendiri. Jika PER lebih rendah dari rata-rata PER historicalnya, maka saham itu relatif lebih murah.

Sebuah studi menemukan bahwa analis yang menggunakan PE menghasilkan hasil jangka pendek yang jauh lebih baik daripada analis yang menggunakan DCF, yaitu ketika akurasi harga target diukur kapan saja selama perkiraan rentang 12 bulan. Namun, tidak ada perbedaan yang 
signifikan dalam kinerja harga target atau kesalahan perkiraan harga target PE dan DCF ketika kinerja analis diukur pada akhir rentang perkiraan.

Rasio PER digunakan untuk melihat apakah suatu saham dihargai dengan Undervalued atau Overvalued - tetapi hanya berfokus pada laba bersih (Earnings) yang tercatat di Laporan Laba Rugi.

PER dapat dihitung dengan menggunakan formula :

$$
\text { Price to Earnings Ratio }(P / \text { E Ratio })=\frac{\text { Harga Saham }}{\text { Laba Bersih per Lembar Saham }}
$$

Sementara rumus untung menghitung Earning per Share adalah :

$$
\text { Earning per Share }(\text { EPS })=\frac{\text { Laba Bersih }}{\text { Jumlah Saham Beredar }}
$$

Rasio P/E ini digunakan untuk mengukur seberapa besar perbandingan antara harga saham perusahaan dengan keuntungan yang diperoleh oleh para pemegang saham. Kegunaan price earning ratio adalah untuk melihat bagaimana pasar menghargai kinerja perusahaan yang dicerminkan oleh earning per share nya. Price earning ratio menunjukkan hubungan antara harga saham dengan laba per lembar saham.

Price earning ratio (PER) berfungsi untuk mengukur perubahan kemampuan laba yang diharapkan di masa yang akan datang. Semakin besar PER, maka semakin besar pula kemungkinan perusahaan untuk tumbuh sehingga dapat meningkatkan nilai perusahaan

Tabel 1

Kelebihan dan Kekurangan Metode P/E Ratio

\begin{tabular}{|l|l|}
\hline Kelebihan Metode P/E Ratio & Kekurangan Metode P/E Ratio \\
\hline - Valuasi P/E Ratio adalah & • Manipulasi Pendapatan \\
metode paling mudah, dengan & P/E ratio memiliki kelemahan manipulasi pendapatan, \\
hasil yang memuaskan. & sejumlah perusahaan yang sengaja menggunakan berbagai \\
- PER terbukti sebagai valuasi & teknik akuntansi untuk mengubah net income yang \\
paling sederhana yang bisa & dilaporkan. manipulasi pendapatan dapat menjerumuskan \\
digunakan investor untuk menilai & investor pada data P/E Ratio yang salah. \\
apakah saham dijual murah atau & • Perbedaan Industri \\
mahal. & Perbedaan industri biasanya memiliki tingkat pertumbuhan \\
& historis, tingkat risiko, dan lain-lainnya yang juga berbeda. \\
& Maka, perbedaan itu juga membuat perbedaan nilai P/E \\
& Ratio. \\
& • Adanya Faktor Lain \\
& P/E ratio hanya menghitung berdasar dua faktor, yaitu harga \\
& saham saat ini dan pendapatan bersih perusahaan tersebut. \\
& P/E ratio akan mengabaikan faktor-faktor lainnya yang \\
& sebenarnya tak kalah pentingnya. Misalnya proyeksi tingkat \\
& pertumbahan di masa depan \\
\hline
\end{tabular}




\section{Arus Kas Diskonto (Discounted Cash Flow atau DCF)}

Metode discounted cash flow merupakan metode yang menggunakan konsep Time Value of Money. Perhitungan metode ini menggunakan arus kas seperti net income, free cash flow, dan operating cash flow yang di hitung future value nya lalu didiskontokan untuk mendapatkan nilai harga wajar saham (Filbert dan Prasetya, 2017:175).

. Seorang analis keuangan tidak akan pernah menggunakan DCF ketika: Ada arus kas yang tidak terduga. Model DCF biasanya akan menggunakan perkiraan arus kas selama bertahun-tahun dan proyeksi pendapatan ini bisa sangat tidak akurat. Menilai lembaga keuangan . Dipercaya secara luas bahwa model DCF tidak cocok ketika menilai lembaga keuangan seperti bank. Lembaga keuangan biasanya beroperasi dengan meminjam dan meminjamkan uang dan bukan melalui arus kas.

Beberapa analis menggunakan model arus kas diskon (DCF) untuk nilai saham, sementara yang lain menggunakan kelipatan harga seperti harga-laba dan rasio nilai harga-buku. Analis teknis percaya bahwa harga didorong sebanyak oleh psikologi investor seperti oleh variabel keuangan yang mendasarinya.

Arus kas diskonto mewakili nilai bersih sekarang (NPV) dari proyeksi Arus Kas yang tersedia untuk semua penyedia modal, setelah dikurangi kas yang diperlukan untuk diinvestasikan menghasilkan pertumbuhan yang diproyeksikan. Tindakan mendiskontokan arus kas masa depan menjawab "berapa banyak uang yang harus diinvestasikan saat ini, pada tingkat pengembalian tertentu, untuk menghasilkan perkiraan arus kas, di masa depan?" Dengan kata lain, diskonto mengembalikan nilai sekarang dari arus kas masa depan, di mana tarif yang digunakan adalah biaya modal yang secara tepat mencerminkan risiko, dan waktu, arus kas.

Konsep penilaian DCF didasarkan pada prinsip bahwa nilai bisnis atau aset secara inheren didasarkan pada kemampuannya untuk menghasilkan arus kas bagi penyedia modal. DCF lebih mengandalkan ekspektasi fundamental bisnis daripada faktor pasar publik atau preseden historis, dan ini adalah pendekatan yang lebih teoritis yang mengandalkan banyak asumsi. Analisis DCF menghasilkan nilai keseluruhan bisnis (yaitu nilai perusahaan) termasuk Hutang dan Ekuitas.

Tabel 2

Kelebihan dan Kekurangan Metode DCF

\begin{tabular}{|l|l|}
\hline Kelebihan Metode DCF & Kekurangan Metode DCF \\
\hline$\bullet$ Secara teoritis, DCF bisa dibilang metode & $\bullet$ Keakuratan penilaian yang ditentukan \\
penilaian yang paling tepat & dengan metode DCF sangat tergantung pada \\
• Metode DCF berwawasan kedepan dan lebih & kualitas asumsi Arus Kas, Nilai Waktu dari \\
bergantung pada ekspektasi masa depan & $\begin{array}{l}\text { Uang (Time Value) dan Tingkat Diskonto } \\
\text { daripada hasil historis }\end{array}$ \\
$\bullet$ Metode DCF lebih melihat kedalam, & Time Value seringkali mewakili presentase \\
mengandalkan nilai tukar ekspektasi \\
fundamental dari bisnis atau aset, dan sedikit \\
dipengaruhi oleh faktor eksternal yang tidak \\
stabil. \\
$\begin{array}{l}\text { - Analisis DCF difokuskan pada perolehan } \\
\text { arus kas dan tidak terpengaruh oleh praktik dan } \\
\text { asumsi akuntansi }\end{array}$ \\
\end{tabular}




\section{SIMPULAN}

Ada beberapa metode untuk menilai perusahaan atau sahamnya, masing-masing dengan kekuatan dan kelemahannya sendiri. Beberapa model mencoba menjabarkan nilai intrinsik perusahaan berdasarkan laporan keuangan dan proyeksinya sendiri, sementara yang lain melihat perbandingan terhadap perusahaan-perusahaan pada industri yang sejenis. Saat memilih metode penilaian, pastikan metode tersebut sesuai untuk perusahaan yang Anda analisis, dan jika lebih dari satu metode valuasi yang sesuai, gunakan keduanya untuk menghasilkan estimasi yang lebih baik.

Metode P/E Ratio didorong oleh kinerja pasar sementara metode DCF didasarkan pada perkiraan analisis arus kas dan tingkat diskonto. Nilai intrinsik saham yang didapatkan berdasarkan hasil analisis fundamental dengan menggunakan DCF dan PER merupakan hasil dari estimasi yang tentunya dapat menghasilkan suatu ketidakpastian, oleh karena itu sebaiknya para investor diharapkan dapat lebih berhati-hati dalam mengambil sebuah keputusan investasi.

Tidak ada metode yang cocok untuk setiap situasi, tetapi dengan mengetahui karakteristik perusahaan, Anda dapat memilih metode valuasi saham yang paling sesuai dengan situasi tersebut. Selain itu, investor tidak dibatasi hanya menggunakan satu model atau metode saja. Dalam menentukan keputusan investasi lebih lanjut, perlu dilakukan analisis yang lebih mendalam dengan mempertimbangkan kondisi internal dan eksternal dari perusahaan sehingga dapat memberikan hasil analisis yang lebih baik.

\section{DAFTAR PUSTAKA}

Brigham, Eugene F and Ehrhardt. 2005. Dasar-Dasar Manajemen Keuangan. Edisi Kesembilan. Alih Bahasa : Jakarta : Salemba Empat

Christiawan, Yulius Jogi dan Josua Tarigan. 2007. Kepemilikan Manajerial : Kebijakan Hutang, Kinerja dan Nilai Perusahaan. Jurnal Akuntansi dan Keuangan,Vol. 9 No.1.

Filbert, Ryan dan William Prasetya. 2017. Investasi Saham Ala Fundamentalis Dunia. Jakarta: PT Elex Media Komputindo

I MadeSudana. 2011. Manajemen Keuangan PerusahaanTeori dan Praktik. Jakarta: Erlangga

Samie Ahmed Sayed. Journal of Accounting in Emerging Economies; Bingley Vol. 7, Iss. 1, (2017): 90-107. DOI:10.1108/JAEE-10-2014-0055

Tandelilin, Eduardus. 2010. Portofolio dan Investasi Teori dan Aplikasi. Edisi Kedua. Yogyakarta: Kanisius. https://www.pikirantrader.com/investasi/18818-kelemahan-price-to-earning-ratio https://pintarsaham.id/metode-valuasi-saham-terbaik-bagi-investor/ 